Supporting information and compound characterization data for:

\title{
Siloxanes with pendent naphthalene diimides: Synthesis and fluorescence quenching
}

\section{Palaniswamy Ganesan $\neq, t$, Barend van Lagen ${ }^{\ddagger}$, Antonius T.} M. Marcelis ${ }^{\ddagger}$, Ernst J. R. Sudhölter, ${ }^{\ddagger}$ and Han Zuilhof ${ }^{\ddagger, \star}$

$\$$ Laboratory of Organic Chemistry, Wageningen University, Dreijenplein 8, 6703 HB Wageningen, The Netherlands. †Dutch Polymer Institute (DPI), P.O. Box 902, 5600 AX Eindhoven, The Netherlands.

Han.Zuilhof@wur.nl

\section{Contents}

1. Experimental descriptions

2. Synthetic route for compound 4 - S3

3. Synthesis of $\mathbf{5}$

4. Synthesis of 6

5. Synthesis of 7

6. Synthesis of $\mathbf{4}$

- S5

7. Synthesis of 1

- S6

8. Synthesis of 2

- S6

9. Synthesis of $\mathbf{3}$

- S7

10. Stereoisomers of 3

11. ${ }^{1} \mathrm{H}$ NMR spectrum of 5

- S9

12. ${ }^{1} \mathrm{H}$ NMR spectrum of 6

- S9

13. ${ }^{1} \mathrm{H}$ NMR spectrum of 7

- S9

14. ${ }^{1} \mathrm{H}$ NMR spectrum of 4

- $\mathrm{S} 10$

15. ${ }^{13} \mathrm{C}$ NMR spectrum of 4

16. ${ }^{1} \mathrm{H}$ NMR spectrum of 1

- S11

17. ${ }^{13} \mathrm{C}$ NMR spectrum of 1

- S11

18. ${ }^{1} \mathrm{H}$ NMR spectrum of 2

- S12

19. ${ }^{13} \mathrm{C}$ NMR spectrum of 2

- S12

20. ${ }^{1} \mathrm{H}$ NMR spectrum of 3

- S13

21. ${ }^{13} \mathrm{C}$ NMR spectrum of 3

- S13

22. HRMS of 4

- S14

23. MALDI-TOF spectrum of $\mathbf{1}$

- S14

24. MALDI-TOF spectrum of 2

- S15

25. MALDI-TOF spectrum of 3

- S15

26. Absorption spectra of $\mathbf{1}$ and $\mathbf{2}$ in films

- S16

27. TCSPC lifetime data

- S 16

28. References

- S16 


\section{Experimental descriptions}

All the chemicals and spectroscopic grade solvents were obtained from Sigma Aldrich. The siloxanes were used after distillation. Spectroscopic grade solvents were freshly distilled over drying agents under nitrogen. ${ }^{1} \mathrm{H}$ and ${ }^{13} \mathrm{C}$ NMR were measured either with Bruker DPX 300 or with Bruker DPX 400 spectrometer. HRMS data were obtained with a Finnigan MAT 95 spectrometer. MALDI-TOF measurements were done with a Bruker-Ultraflex spectrometer. UV-vis spectra were measured either with a Varian Cary 50 or with a Cary 100 spectrophotometer. Steady state fluorescence spectra were recorded using a Spex Fluorolog 3.22 spectrophotometer. Time-resolved fluorescence measurements were carried out using mode-locked laser for excitation and time-correlated photon counting as detection technique. The pump laser was a CW diode-pumped, frequency-doubled Nd:YVO4 laser (Coherent Inc., Verdi V10). The mode-locked laser was a Ti:sapphire laser (Coherent Inc., Mira 900-D in ps mode, FWHM 3 ps), tuned to $780 \mathrm{~nm}$. The output of the Ti:sapphire laser passed through a pulse picker (APEGmbH, Pulse Select), to bring down the repetition rate of excitation pulses to $3.8 \times 10^{6}$ pulse per second. The output of the pulse picker was directed towards a frequency doubler (Inrad Inc., 5-050, Ultrafast Harmonic Generation System). The excitation pulses did have energies in the $\mathrm{nJ}$ region, an excitation wavelength of $390 \mathrm{~nm}$ and a pulse duration of less than 0.2 ps. Detection electronics were time-correlated single photon counting modules. With a small portion of the mode-locked light at $780 \mathrm{~nm}$ wavelength (left from the harmonics conversion) a fast photodiode (Becker \& Hickl model PHD-400) was excited. The output pulses of this photodiode were fed to one channel of a quad constant fraction discriminator (CFD, Tennelec Inc., Oak Ridge, TS, modified model TC 454), and then used as stop signal for a time-to-amplitude converter (TAC, Tennelec Inc., Oak Ridge, TS, model TC 864). A microchannel plate photomultiplier (Hamamatsu, Hamamatsu, Japan, model R3809U-50 at 
$3100 \mathrm{~V}$, cooled down by a water bath to a few degrees centigrade) was used for the detection of the fluorescence photons. The single photon responses of this PMT were amplified by a wide-band amplifier (Becker \& Hickl GmbH, Berlin, Germany, model ACA-2; $21 \mathrm{~dB}, 1.8$ GHz), analyzed in another channel of the CFD and then used as a start signal for the TAC. The output pulses of the TAC were analyzed by an analogue-to-digital converter (ADC, Nuclear Data Inc., Schaumburg, IL, model 8715, 800 ns fixed dead-time), used in Coincidence and Sampled Voltage Analysis mode, gated by the Valid Conversion Output of the TAC. The output of the ADC was gathered in 4096 channels of a multichannel analyzer (MCA board from Nuclear Data Inc., Schaumburg, IL, model AccuspecB, in a personal computer). The channel time spacing was 5.0 ps.

Nanosecond laser flash photolysis studies and time-resolved fluorescence studies were carried out with an excitation wavelength of $355 \mathrm{~nm}$ from the $3 \omega$ of a Nd:YAG laser (Brilliant FWHM = 4 ns, Quantal Inc.) and the signals were detected using LP920-spectrophotometer (Edinburgh Instruments Limited) fitted with $450 \mathrm{~W}$ Xe arc lamp as a probe and a red-sensitive photomultiplier (R928, Hamamatsu) and ICCD camera (DH720, Andor Technology) as detectors.

\section{Synthetic route for compound 4}
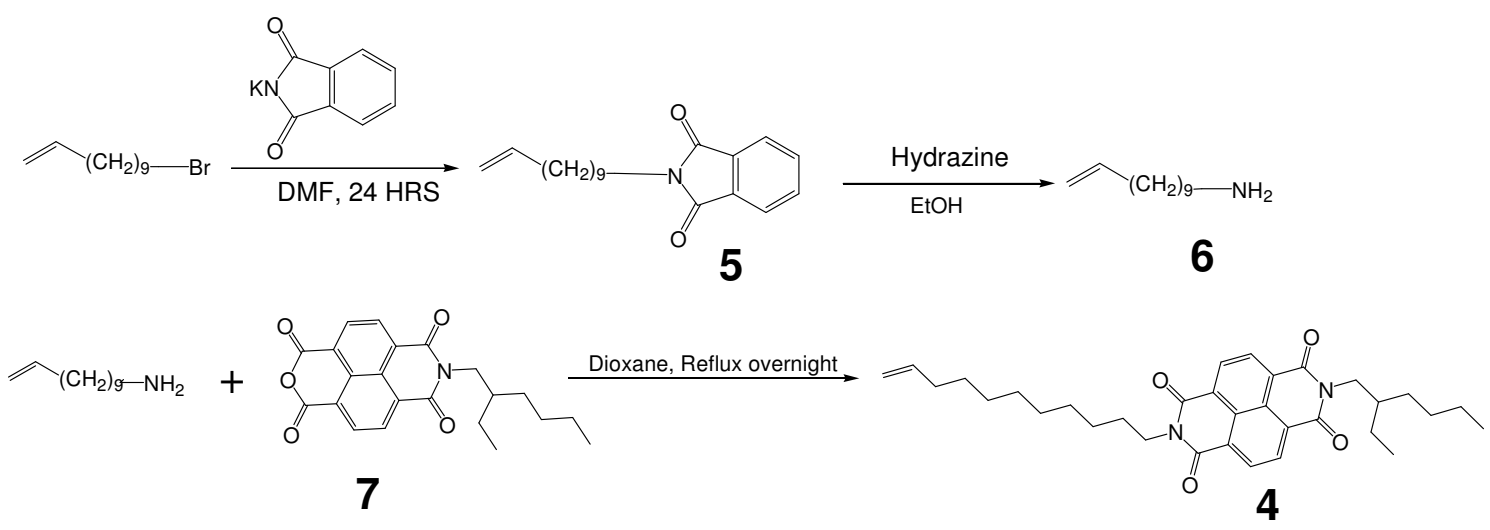
N-(10-Undecylenyl)-Phthalimide 5: $10.00 \mathrm{~g}$ (42.88 mmol) of 1-bromo-10-undecene and $10.33 \mathrm{~g}(55.77 \mathrm{mmol})$ of potassium phthalimide were taken in $25 \mathrm{ml}$ of freshly distilled DMF. The resulting mixture was stirred at $90{ }^{\circ} \mathrm{C}$ for $24 \mathrm{hrs}$. The reaction mixture was cooled to room temperature and $75 \mathrm{ml}$ of water was added. This mixture was extracted with ether $(1 \mathrm{x}$ $75 \mathrm{ml}, 2 \times 30 \mathrm{ml}$ ). The ether layer was washed with $25 \mathrm{ml}$ of $0.2 \mathrm{~N} \mathrm{NaOH}$ solution and with $25 \mathrm{ml}$ of brine. The organic layer was dried with $\mathrm{MgSO}_{4}$ and evaporated. The yellow crude product was recrystallized from distilled methanol to yield $9.70 \mathrm{~g}(32.39 \mathrm{mmol}, 75.5 \%)$ of $\mathrm{N}$ ( $\omega$-Undecylenyl)-phthalimide as white crystals. ${ }^{1} \mathrm{H}$ NMR $\left(300 \mathrm{MHz}, \mathrm{CDCl}_{3}\right) \delta 7.83(\mathrm{~m}, 2 \mathrm{H}$, Ar), $7.73(\mathrm{~m}, 2 \mathrm{H}, \mathrm{Ar}), 5.80\left(\mathrm{~m}, 1 \mathrm{H},-\mathrm{CH}=\mathrm{CH}_{2}\right), 4.96\left(\mathrm{~m}, 2 \mathrm{H},-\mathrm{CH}=\mathrm{CH}_{2}\right), 3.68\left(\mathrm{t}, 2 \mathrm{H},-\mathrm{N}-\mathrm{CH}_{2}-\right.$ ), $2.02\left(\mathrm{~m}, 2 \mathrm{H},-\mathrm{CH}_{2}-\mathrm{CH}=\mathrm{CH}_{2}\right), 1.69\left(\mathrm{t}, 2 \mathrm{H}, \mathrm{N}-\mathrm{CH}_{2}-\mathrm{CH}_{2}\right), 1.32\left(\mathrm{~m}, 12 \mathrm{H}, 6 \times \mathrm{CH}_{2}\right)$, in line with reported NMR data. [Sieval, A. B.; Linke, R.; Heij, G.; Meijer, G.; Zuilhof, H.; Sudhölter, E. J. R. Langmuir 2001, 17, 7554-7559.]

1-Amino-10-undecene 6: To a solution of $9.67 \mathrm{~g}$ (32.29 mmol) of $\mathrm{N}$-(10-undecylenyl)phthalimide in $100 \mathrm{ml}$ ethanol, $2.41 \mathrm{~g}(48.2 \mathrm{mmol})$ of hydrazine monohydrate was added. This mixture was refluxed for $3 \mathrm{hrs}$ and cooled to room temperature. The $\mathrm{pH}$ of the solution was adjusted to 1-2 using $1 \mathrm{M} \mathrm{HCl}$. The white suspension that formed was filtered and washed with $1 \mathrm{M} \mathrm{HCl}$. The filtrate was made alkaline to a $\mathrm{pH}$ of $10-11$ by addition of $\mathrm{NaOH}$ pellets and concentrated to get a turbid aqueous layer. This was extracted with ether $(4 \mathrm{x} 50$ $\mathrm{ml}$ ). The combined organic layers were washed with $20 \mathrm{ml}$ of $0.2 \mathrm{~N} \mathrm{NaOH}$ solution and $20 \mathrm{ml}$ of brine with few $\mathrm{ml}$ of $0.2 \mathrm{~N} \mathrm{NaOH}$ solution. The organic layer was dried over $\mathrm{NaOH}$ pelletes for couple of hours and evaporated to get $3.80 \mathrm{~g}(22.44 \mathrm{mmol}, 69.5 \%)$ of 1-amino10-undecene as oily substance. ${ }^{1} \mathrm{H}$ NMR $\left(300 \mathrm{MHz}, \mathrm{CDCl}_{3}\right) \delta 5.82\left(\mathrm{~m}, 1 \mathrm{H},-\mathrm{CH}=\mathrm{CH}_{2}\right), 4.96$ $\left(\mathrm{m}, 2 \mathrm{H},-\mathrm{CH}=\mathrm{CH}_{2}\right), 2.67\left(\mathrm{t}, 2 \mathrm{H},-\mathrm{N}-\mathrm{CH}_{2-}\right), 2.02\left(\mathrm{q}, 2 \mathrm{H},-\mathrm{CH}_{2}-\mathrm{CH}=\mathrm{CH}_{2}\right), 1.32(\mathrm{~m}, 16 \mathrm{H}$, 
$7 \times \mathrm{CH}_{2}$ and $-\mathrm{NH}_{2}$ ), in line with reported NMR data. [Sieval, A. B.; Linke, R.; Heij, G.; Meijer, G.; Zuilhof, H.; Sudhölter, E. J. R. Langmuir 2001, 17, 7554-7559.]

N-(2-ethylhexyl)naphthalenemonoimidemonoanhyride 7: Naphthalenedianhydride (20.02 $\mathrm{g}, 74.65 \mathrm{mmol}$ ) was taken in a three necked flask with $200 \mathrm{ml}$ of freshly distilled DMF. The slurry is heated to about $140^{\circ} \mathrm{C}$ under $\mathrm{N}_{2}$ atmosphere. To this 2-ethylhexylamine $(9.65 \mathrm{~g}$, 74.64mmol) was added drop wise for about 10 minutes and the reaction mixture was refluxed overnight, under $\mathrm{N}_{2}$ atmosphere. Reaction mixture cooled and the precipitated diimide were filtered off. DMF was evaporated under low pressure and the residue dissolved in dichloromethane to remove the insoluble. Dichloromethane evaporated and the crude material was purified on silica column with dichloromethane as eluent to obtain $7.1 \mathrm{~g}$ ( $25 \%$ yield) of the desired product as a pale yellow-orange solid. ${ }^{1} \mathrm{H} \mathrm{NMR}\left(400 \mathrm{MHz}, \mathrm{CDCl}_{3}\right) \delta 8.83(\mathrm{~s}, 4 \mathrm{H}$, Naphth-H), 4.11 (m, 2H, -N-CH$\left.H_{2}\right), 1.94\left(\mathrm{~m}, 1 \mathrm{H},-\mathrm{CH}_{2}-\mathrm{CH}-\mathrm{CH}_{2}\right), 1.35\left(\mathrm{~m}, 8 \mathrm{H}, 4 \times \mathrm{CH}_{2}\right), 0.95(\mathrm{t}$, $3 \mathrm{H}, J=7.4 \mathrm{~Hz}), 0.89(\mathrm{t}, 3 \mathrm{H}, J=7.2 \mathrm{~Hz})$ in line with reported NMR data [Ganesan, P.; Yang, X. N.; Loos, J.; Savenije, T. J.; Abellon, R. D.; Zuilhof, H.; Sudhölter, E. J. R. J. Am. Chem. Soc. 2005, 127, 14530-14531.]

N-(2-ethylhexyl)-N'- (10-undecenenyl)naphthalenediimide 4: To a solution of $1.05 \mathrm{~g}$ of N(2-ethylhexyl)naphthalene monoimide monoanhydride $(2.77 \mathrm{mmol})$ in 1,4-dioxane, $0.47 \mathrm{~g}$ of 1-amino-10-undecene $(2.77 \mathrm{mmol})$ in $10 \mathrm{ml}$ of dioxane was added drop wise at about $70{ }^{\circ} \mathrm{C}$. This reaction mixture was refluxed overnight under nitrogen atmosphere. The reaction mixture was cooled to room temperature and the solvent evaporated. The crude product was loaded on a silica gel column and eluted with dichloromethane to get $1.15 \mathrm{~g}(2.17 \mathrm{mmol}$, $78 \%)$ of the product as white/light yellow solid. ${ }^{1} \mathrm{H}$ NMR $\left(300 \mathrm{MHz}, \mathrm{CDCl}_{3}\right) \delta 8.74(\mathrm{~s}, 4 \mathrm{H}$, Naphth-H), $5.79\left(\mathrm{~m}, 1 \mathrm{H},-\mathrm{CH}=\mathrm{CH}_{2}\right), 5.94\left(\mathrm{~m}, 2 \mathrm{H},-\mathrm{CH}=\mathrm{CH}_{2}\right), 4.16\left(\mathrm{~m}, 4 \mathrm{H},-\mathrm{N}-\mathrm{CH}_{2^{-}}\right), 2.04$ $\left(\mathrm{m}, 2 \mathrm{H},-\mathrm{CH}_{2}-\mathrm{CH}=\mathrm{CH}_{2}\right), 2.02\left(\mathrm{~m}, 1 \mathrm{H},-\mathrm{CH}_{2}-\mathrm{CH}-\mathrm{CH}_{2}-\right), 1.74\left(\mathrm{~m}, 2 \mathrm{H}, \mathrm{N}-\mathrm{CH}_{2}-\mathrm{CH}_{2}-\right), 1.36(\mathrm{~m}$, $\left.20 \mathrm{H}, 10 \times \mathrm{CH}_{2}\right), 0.94\left(\mathrm{~m}, 6 \mathrm{H}, 2 \times \mathrm{CH}_{3}\right) ;{ }^{13} \mathrm{C} \mathrm{NMR} \delta 163.8,163.42,139.79,131.58,131.52$, 
$127.32,127.28,127.20,45.21,41.56,38.54,34.38,31.30,30.03,29.99,29.88,29.67,29.50$, 29.22, 28.67, 27.65, 24.64, 23.62, 14.65, 11.19; HRMS calculated for $\mathrm{C}_{33} \mathrm{H}_{42} \mathrm{~N}_{2} \mathrm{O}_{4} 530.3138$, found 530.3145 .

\section{1,1,3,3,5,5-Hexamethyl-1,5-bis(N-(2-ethylhexyl)-N'-(undecenyl)naphthalenediimide)}

trisiloxane 1: $1.25 \mathrm{~g}$ (2.36 mmol) of N-(2-ethylhexyl)-N'-(10-undecenyl) naphthalenediimide and $0.2 \mathrm{~g}$ (0.96 mmol) 1,1,3,3,5,5-hexamethyltrisiloxane were taken in $20 \mathrm{ml}$ of dry toluene. The flask with the reaction mixture was purged with argon while it was warmed up to $70{ }^{\circ} \mathrm{C}$ and $5 \mu \mathrm{l}$ of catalyst (platinum(0)-1,3-divinyl-1,1,3,3-tetramethyldisiloxane complex; $0.10 \mathrm{M}$ solution in xylenes) was added using a syringe. This mixture was stirred for $2 \mathrm{~h}$ at $70{ }^{\circ} \mathrm{C}$ and then cooled down to room temperature. Solvent was evaporated under reduced pressure and the crude product was purified using silica gel column with dichloromethane as eluent to get $0.65 \mathrm{~g}(0.51 \mathrm{mmol}, 53.4 \%)$ of the dimer. ${ }^{1} \mathrm{H} \mathrm{NMR}\left(300 \mathrm{MHz}, \mathrm{CDCl}_{3}\right) \delta 8.69$ (s, 8H, Naphth$\mathrm{H}), 4.11\left(\mathrm{~m}, 8 \mathrm{H},-\mathrm{N}-\mathrm{CH}_{2^{-}}\right), 1.89\left(\mathrm{~m}, 2 \mathrm{H},-\mathrm{CH}_{2}-\mathrm{CH}-\mathrm{CH}_{2}-\right), 1.69\left(\mathrm{~m}, 4 \mathrm{H}, \mathrm{N}-\mathrm{CH}_{2}-\mathrm{CH}_{2^{-}}\right), 1.33$ $\left(\mathrm{m}, 48 \mathrm{H}, 24 \times \mathrm{CH}_{2}\right), 0.89\left(\mathrm{~m}, 12 \mathrm{H}, 4 \times \mathrm{CH}_{3}\right), 0.45\left(\mathrm{t}, 4 \mathrm{H},-\mathrm{Si}-\mathrm{CH}_{2^{-}}\right), 0.0\left(\mathrm{~s}, 12 \mathrm{H}, 2 \mathrm{x}-\mathrm{CH}_{2^{-}}\right.$ $\left.\mathrm{Si}\left(\mathrm{CH}_{3}\right)_{2}-\right),-0.02\left(\mathrm{~s}, 6 \mathrm{H},-\mathrm{O}-\mathrm{Si}\left(\mathrm{CH}_{3}\right)_{2}-\mathrm{O}-\right) ;{ }^{13} \mathrm{C} \mathrm{NMR} \delta 163.00,162.60,130.77,126.47,44.40$, $40.78,37.73,33.27,30.49,29.44,29.39,29.35,29.20,29.14,28.41,27.89,26.90,23.83$, 23.03, 22.81, 18.10, 13.84, 10.38, 0.98, 0.00; MALDI-TOF calculated for $\mathrm{C}_{72} \mathrm{H}_{104} \mathrm{~N}_{4} \mathrm{O}_{10} \mathrm{Si}_{3}$ 1268.706, found 1268.704 .

\section{2,4,6,8-Tetramethyl-2,4,6,8-tetra(N-(2-ethylhexyl)-N'-(undecenyl)naphthalenediimide)}

cyclotetrasiloxane $\quad 2: \quad 1.31 \mathrm{~g} \quad(2.47 \mathrm{mmol})$ of $\mathrm{N}$-(2-ethylhexyl)-N'-(10-undecenyl) naphthalenediimide and $0.135 \mathrm{~g}(0.56 \mathrm{mmol})$ 2,4,6,8-tetramethylcyclotetrasiloxane were taken in $20 \mathrm{ml}$ of dry toluene. The flask with the reaction mixture was purged with argon while it is warmed up to $70{ }^{\circ} \mathrm{C}$ and $5 \mu$ of catalyst (platinum(0)-1,3-divinyl-1,1,3,3tetramethyl disiloxane complex; $0.10 \mathrm{M}$ solution in xylenes) was added using a syringe. This mixture was stirred for $40 \mathrm{~h}$ at $70{ }^{\circ} \mathrm{C}$ and then cooled down to room temperature. Solvent was 
evaporated under reduced pressure and recrystallized from dichloromethane. The recrystallized product was purified using a silica gel column with chloroform as eluent to get $0.66 \mathrm{~g}(0.28 \mathrm{mmol}, 50.0 \%)$ of the tetramer. ${ }^{1} \mathrm{H} \mathrm{NMR}\left(300 \mathrm{MHz}, \mathrm{CDCl}_{3}\right) \delta 8.69-8.63(6 \mathrm{~s}$, 16H, Naphth-H), 4.10 (m, 16H, -N-CH $\left.2^{-}\right), 1.89$ (m, 4H, $\left.-\mathrm{CH}_{2}-\mathrm{CH}-\mathrm{CH}_{2^{-}}\right), 1.65$ (m, 8H, N$\left.\mathrm{CH}_{2}-\mathrm{CH}_{2^{-}}\right), 1.32\left(\mathrm{~m}, 96 \mathrm{H}, 48 \times \mathrm{CH}_{2}\right), 0.85\left(\mathrm{~m}, 24 \mathrm{H}, 8 \times \mathrm{CH}_{3}\right), 0.4\left(\mathrm{t}, 8 \mathrm{H}, 4 \mathrm{x}\left(-\mathrm{Si}-\mathrm{CH}_{2}\right)\right), 0.0$ (s, 12H, 4x (-O-Si $\left.\left.\left(\mathrm{CH}_{3}\right)-\mathrm{O}-\right)\right) ;{ }^{13} \mathrm{C}$ NMR $\delta 163.77,162.33,131.49,127.24,45.20,41.58,38.53$, $33.82,31.29,30.25,29.99,29.65,28.70,27.74,24.63,23.63,17.80,14.66,11.18,0.00$; MALDI-TOF calculated for $\mathrm{C}_{136} \mathrm{H}_{184} \mathrm{~N}_{8} \mathrm{O}_{20} \mathrm{Si}_{4}$ 2361.270, found 2361.307.

\section{2,4,6,8,10-Pentamethyl-2,4,6,8,10-penta(N-(2-ethylhexyl)-N'-(undecenyl)}

naphthalenediimide)cyclopentasiloxane 3: $1.56 \mathrm{~g}$ (2.94 mmol) of N-(2-ethylhexyl)-N'- (10undecenyl)naphthalenediimide and $0.161 \mathrm{~g} \quad(0.54 \mathrm{mmol})$ of $2,4,6,8,10-$ pentamethylcyclopentasiloxane were taken in $20 \mathrm{ml}$ of dry toluene. The flask with the reaction mixture was purged with argon while it is warmed up to $70{ }^{\circ} \mathrm{C}$ and $10 \mu \mathrm{l}$ of catalyst (platinum(0)-1,3-divinyl-1,1,3,3-tetramethyl disiloxane complex; $0.10 \mathrm{M}$ solution in xylenes) was added using a syringe. This mixture stirred for $60 \mathrm{~h}$ at $70{ }^{\circ} \mathrm{C}$ and then cooled to room temperature. Solvent was evaporated under reduced pressure. The crude product was purified using a silica gel column with $2 \%$ ethyl acetate in dichloromethane as eluent to get pure pentamer 3. ${ }^{1} \mathrm{H}$ NMR $\left(300 \mathrm{MHz}, \mathrm{CDCl}_{3}\right) \delta 8.69-8.63(7 \mathrm{~s}, 20 \mathrm{H}$, Naphth-H), $4.10(\mathrm{~m}, 20 \mathrm{H},-\mathrm{N}-$ $\mathrm{CH}_{2^{-}}$), $1.95\left(\mathrm{~m}, 5 \mathrm{H},-\mathrm{CH}_{2}-\mathrm{CH}-\mathrm{CH}_{2}-\right), 1.70\left(\mathrm{~m}, 10 \mathrm{H}, \mathrm{N}-\mathrm{CH}_{2}-\mathrm{CH}_{2^{-}}\right), 1.32\left(\mathrm{~m}, 120 \mathrm{H}, 60 \times \mathrm{CH}_{2}\right)$, $0.96\left(\mathrm{~m}, 30 \mathrm{H}, 10 \times \mathrm{CH}_{3}\right), 0.5\left(\mathrm{t}, 10 \mathrm{H}, 5 \mathrm{x}\left(-\mathrm{Si}-\mathrm{CH}_{2}\right)\right), 0.0\left(\mathrm{~s}, 15 \mathrm{H}, 5 \mathrm{x}\left(-\mathrm{O}-\mathrm{Si}\left(\mathrm{CH}_{3}\right)-\mathrm{O}-\right)\right) ;{ }^{13} \mathrm{C}$ NMR $\delta 163.21,162.19,131.38,127.11,45.10,41.50,38.45,33.89,30.04,30.01,29.98$, 29.93, 29.14, 28.63, 27.68, 23.64, 23.56, 17.95, 14.60, 11.11, 0.00; MALDI-TOF calculated for $\mathrm{C}_{170} \mathrm{H}_{230} \mathrm{~N}_{10} \mathrm{O}_{25} \mathrm{Si}_{5} 2951.588$, found 2951.966. 


\section{Stereoisomers of 3.}

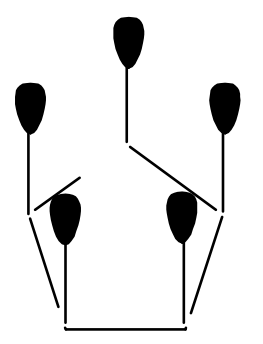

3a

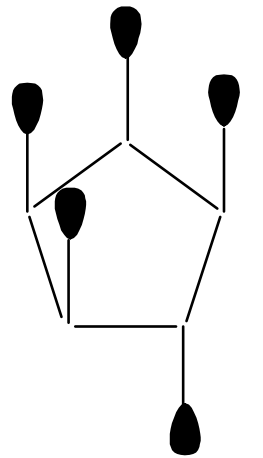

$3 b$

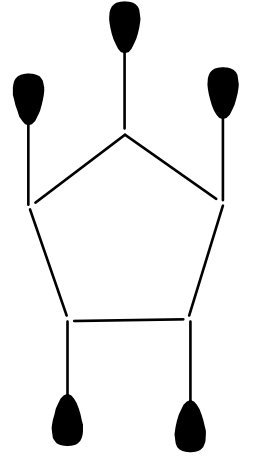

$3 c$

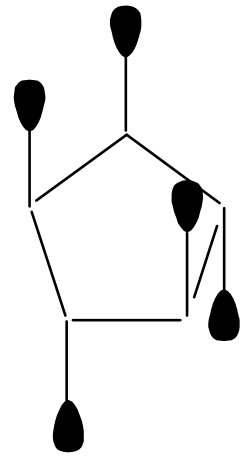

3d

The naphthalenediimide groups in isomers $\mathbf{3 b}, \mathbf{3 c}$ and $\mathbf{3 d}$ occur in three different environments, each. Therefore, each peak of these three isomers would split at a ratio of $2: 2$ : 1. Thus in total 10 different peaks for the naphthalenediimide aromatics could be expected. Given the high similarity of these environments, it is likely that some of these peaks would overlap, which would reduce the number of observed peaks to $<10$. This is indeed our observation (7 peaks are seen).

\section{${ }^{1} \mathrm{H}$ NMR of $\mathrm{N}$-(10-Undecylenyl)-Phthalimide $\mathbf{5}$}
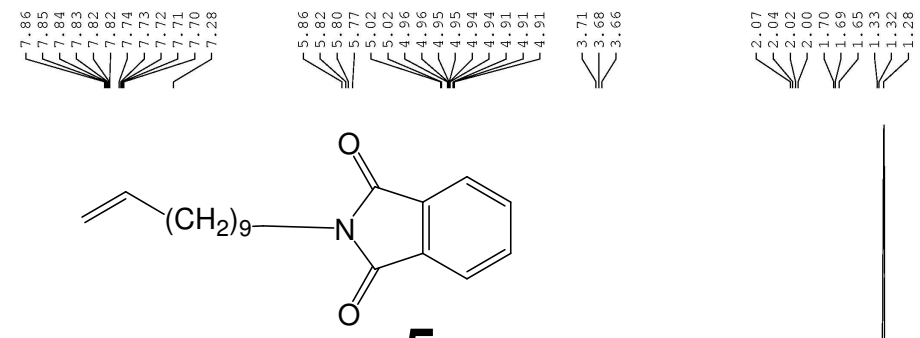

5

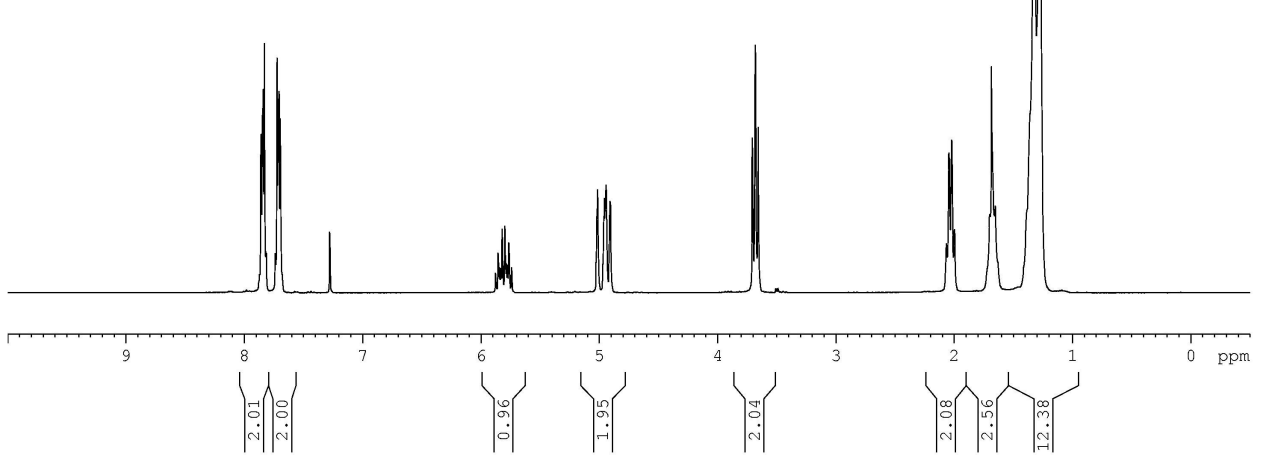




\section{${ }^{1} \mathrm{H}$ NMR of 1-Amino-10-undecene 6}

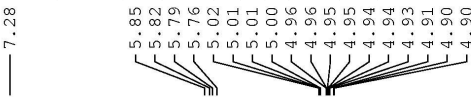

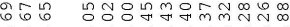

$+1+1$

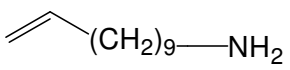

6

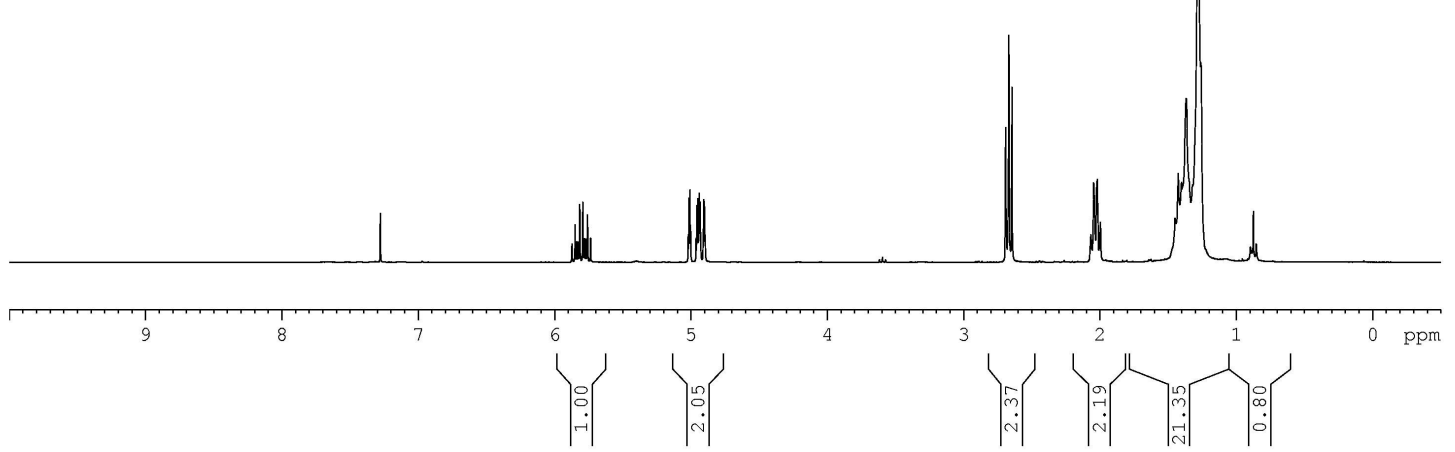

${ }^{1} \mathrm{H}$ NMR of $\mathrm{N}$-(2-ethylhexyl)naphthalene monoimide monoanhydride 7
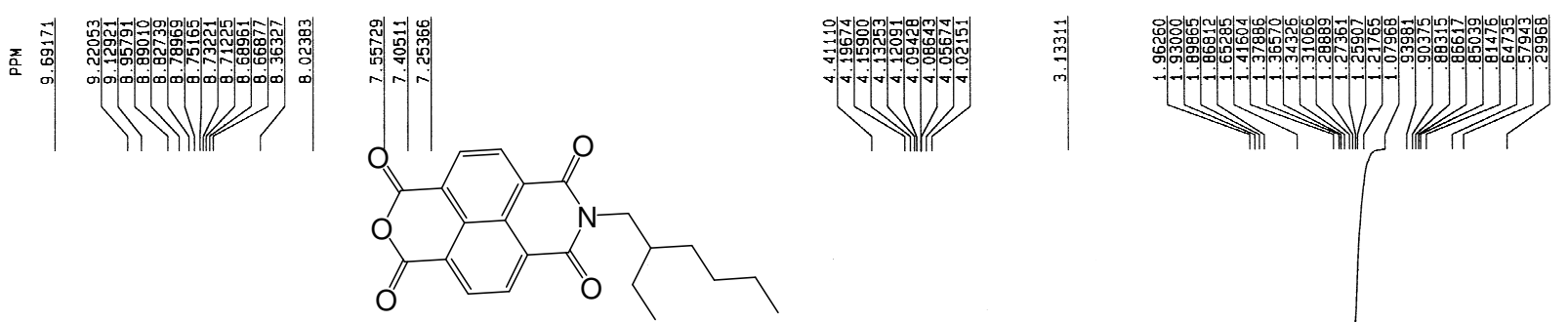

7
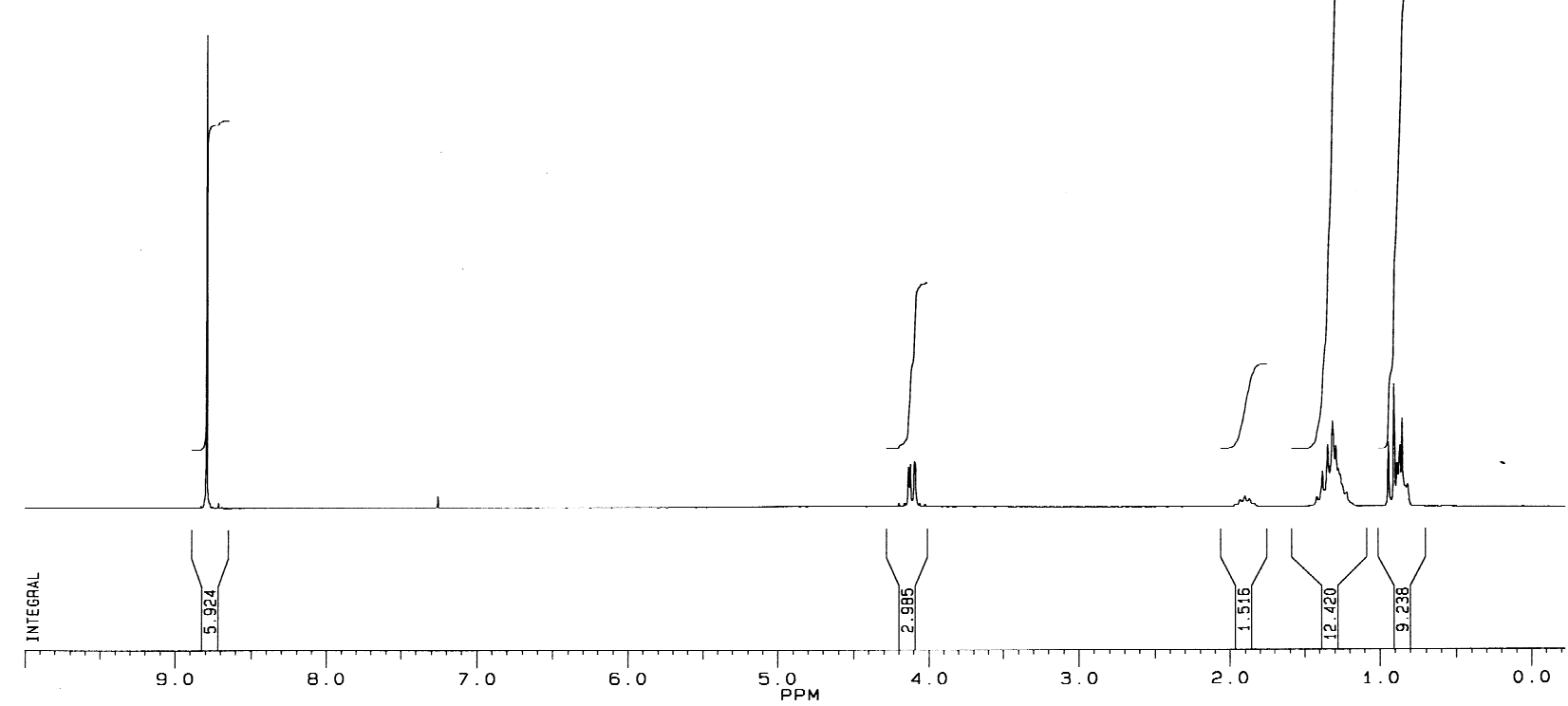
${ }^{1} \mathrm{H}$ NMR of N-(2-ethylhexyl)-N'- (10-undecenyl)naphthalene diimide 4

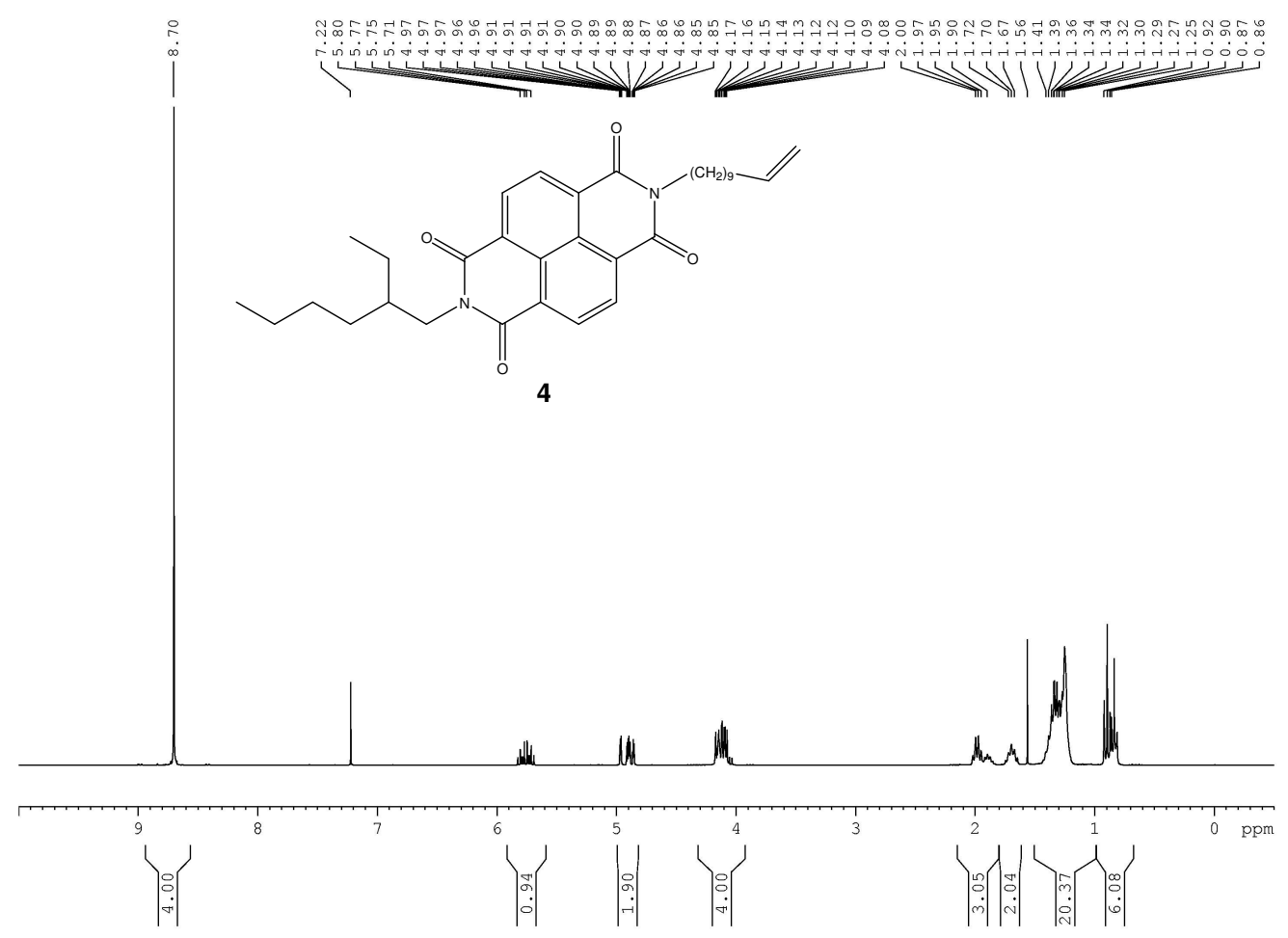

${ }^{13} \mathrm{C}$ NMR of N-(2-ethylhexyl)-N'- (10-undecenyl)naphthalene diimide 4

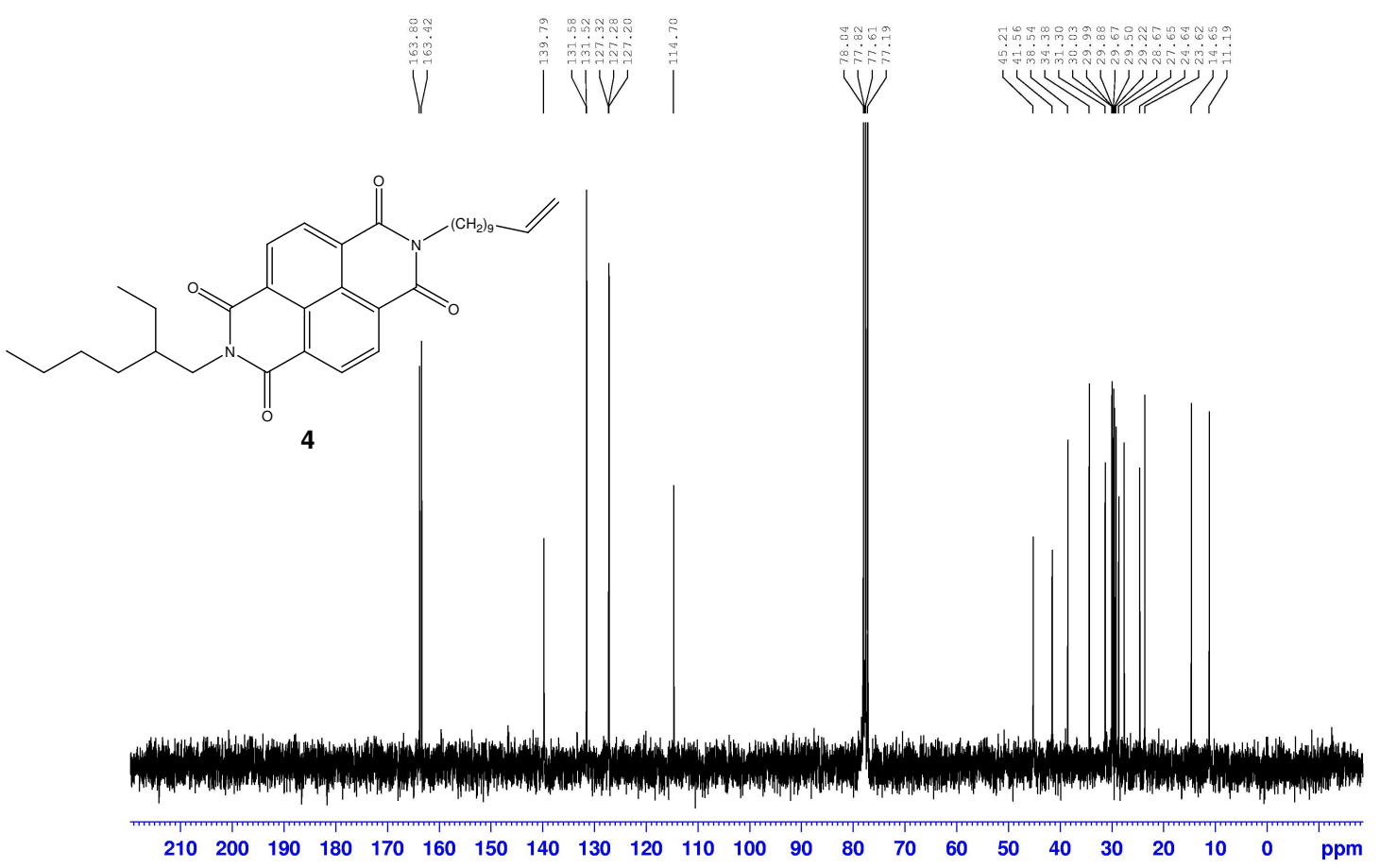




\section{${ }^{1} \mathrm{H}$ NMR of Dimer 1}

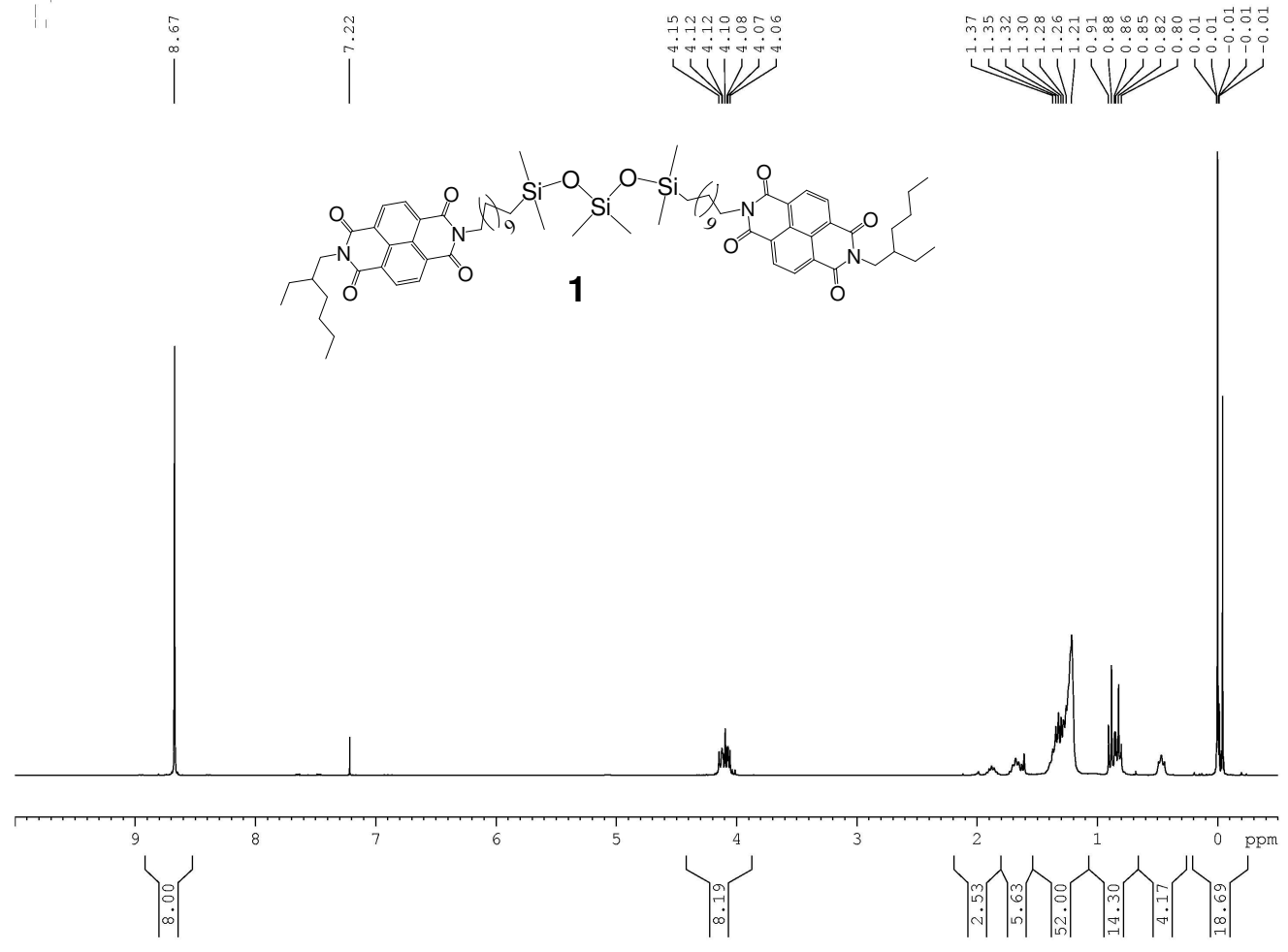

\section{${ }^{13} \mathrm{C}$ NMR of Dimer 1}

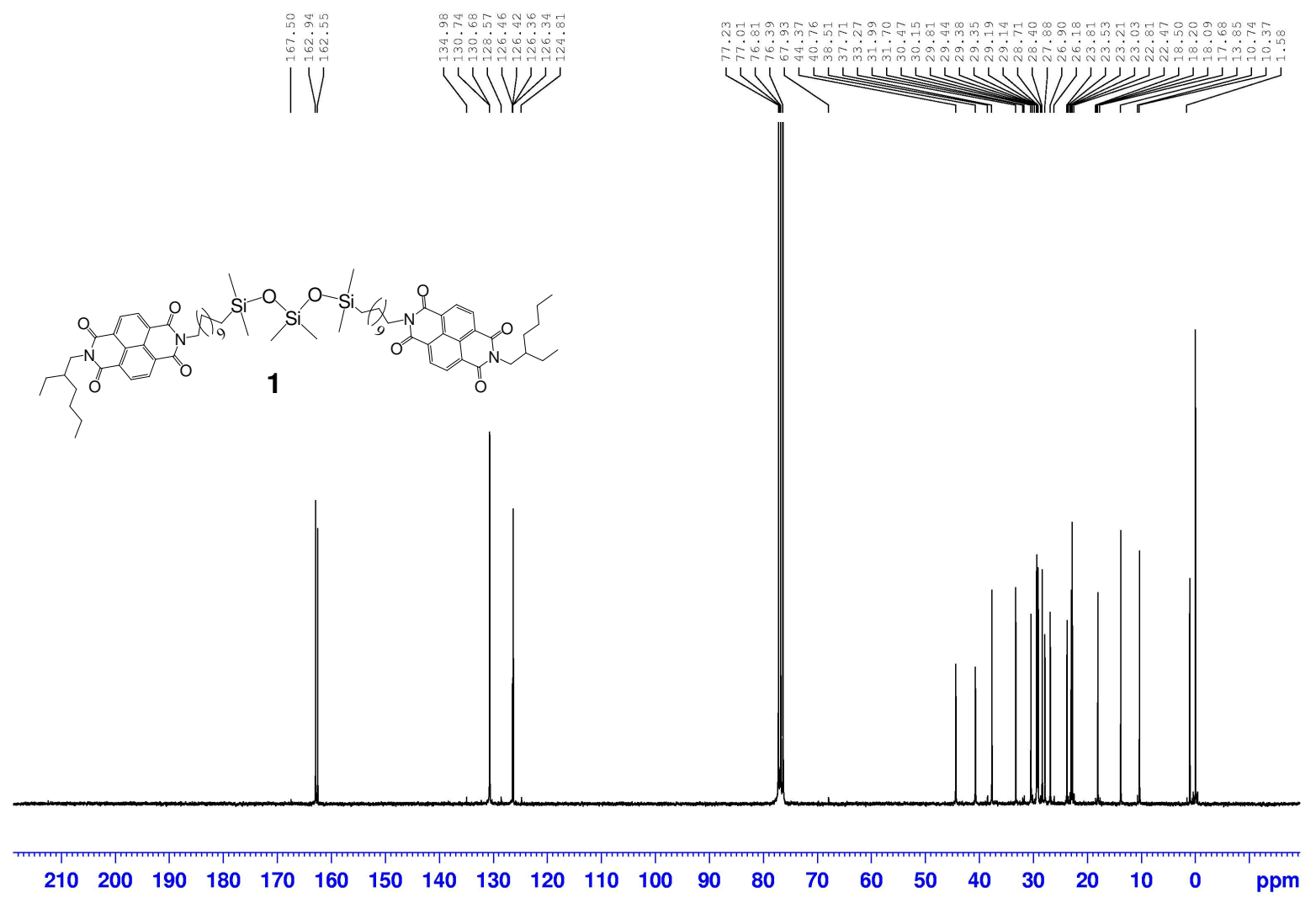


${ }^{1} \mathrm{H}$ NMR of Tetramer 2

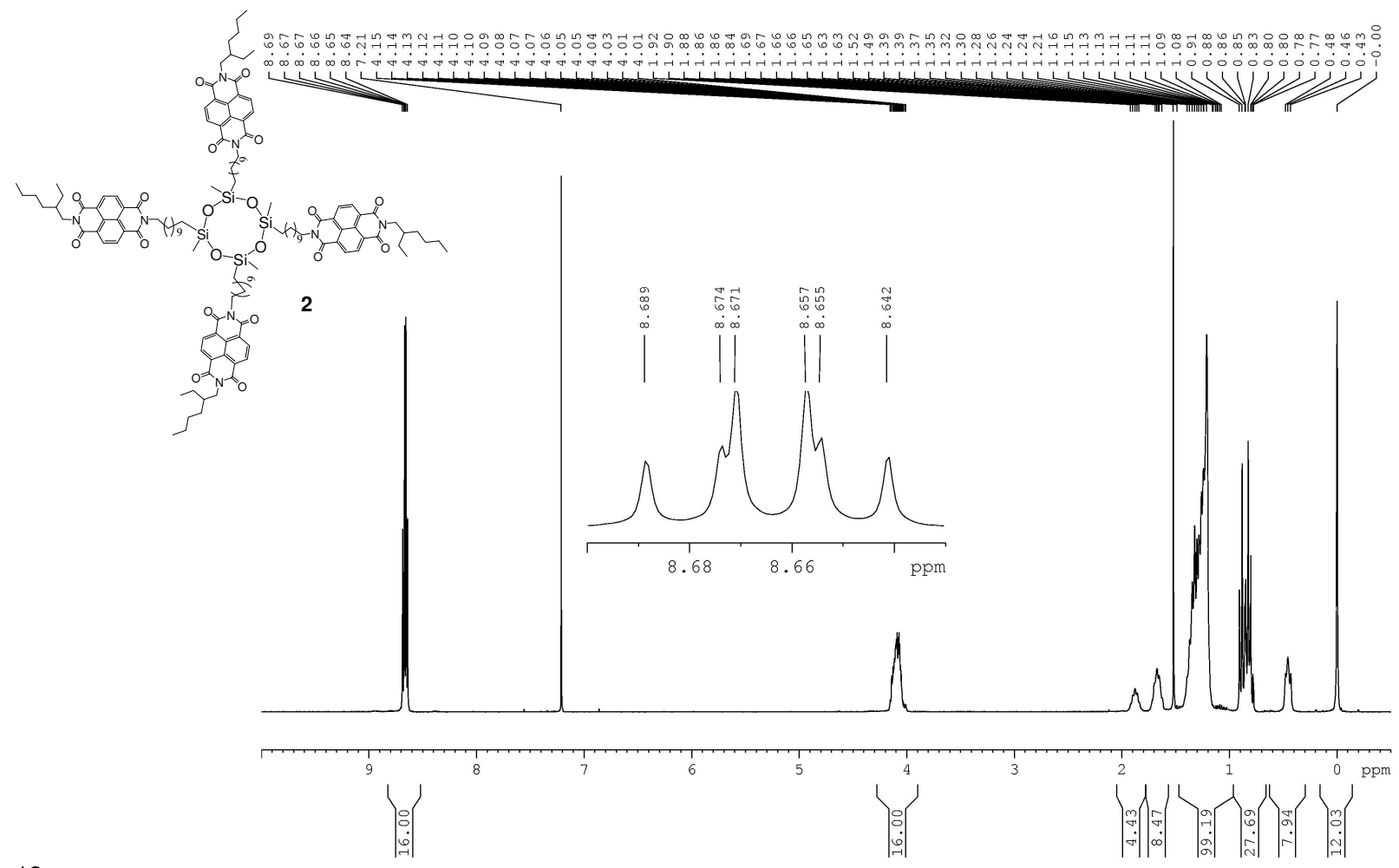

${ }^{13} \mathrm{C}$ NMR of Tetramer 2
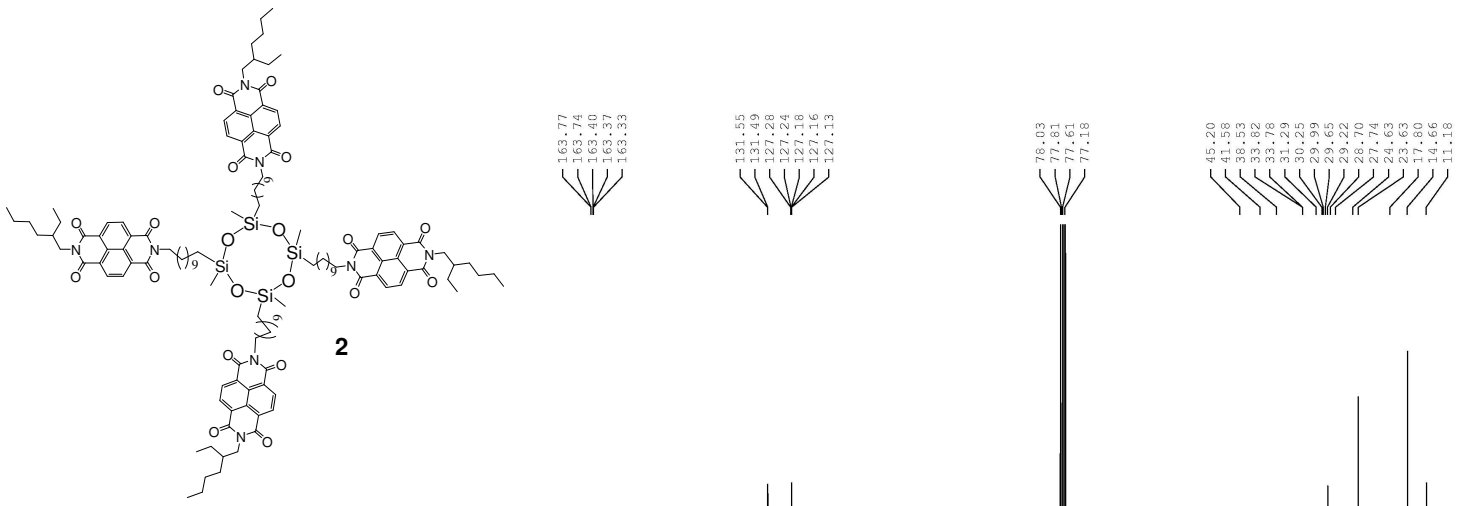

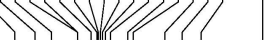

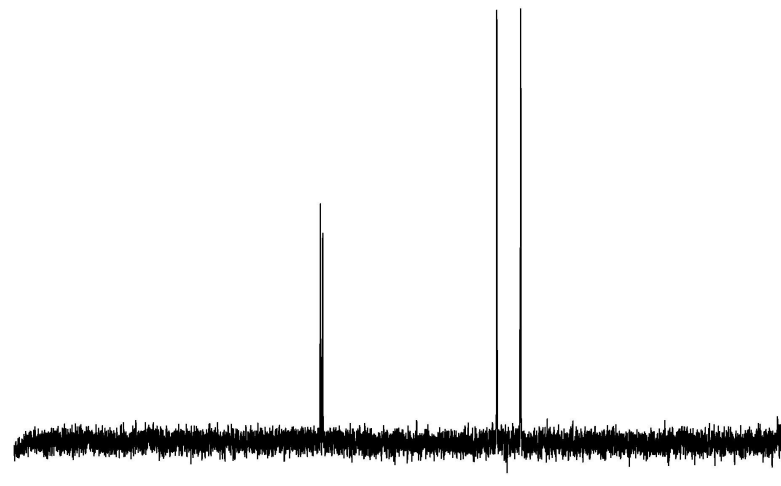

$\begin{array}{lllllllllllllllllllllll}210 & 200 & 190 & 180 & 170 & 160 & 150 & 140 & 130 & 120 & 110 & 100 & 90 & 80 & 70 & 60 & 50 & 40 & 30 & 20 & 10 & 0 & \mathrm{ppm}\end{array}$ 


\section{${ }^{1} \mathrm{H}$ NMR of Pentamer 3}

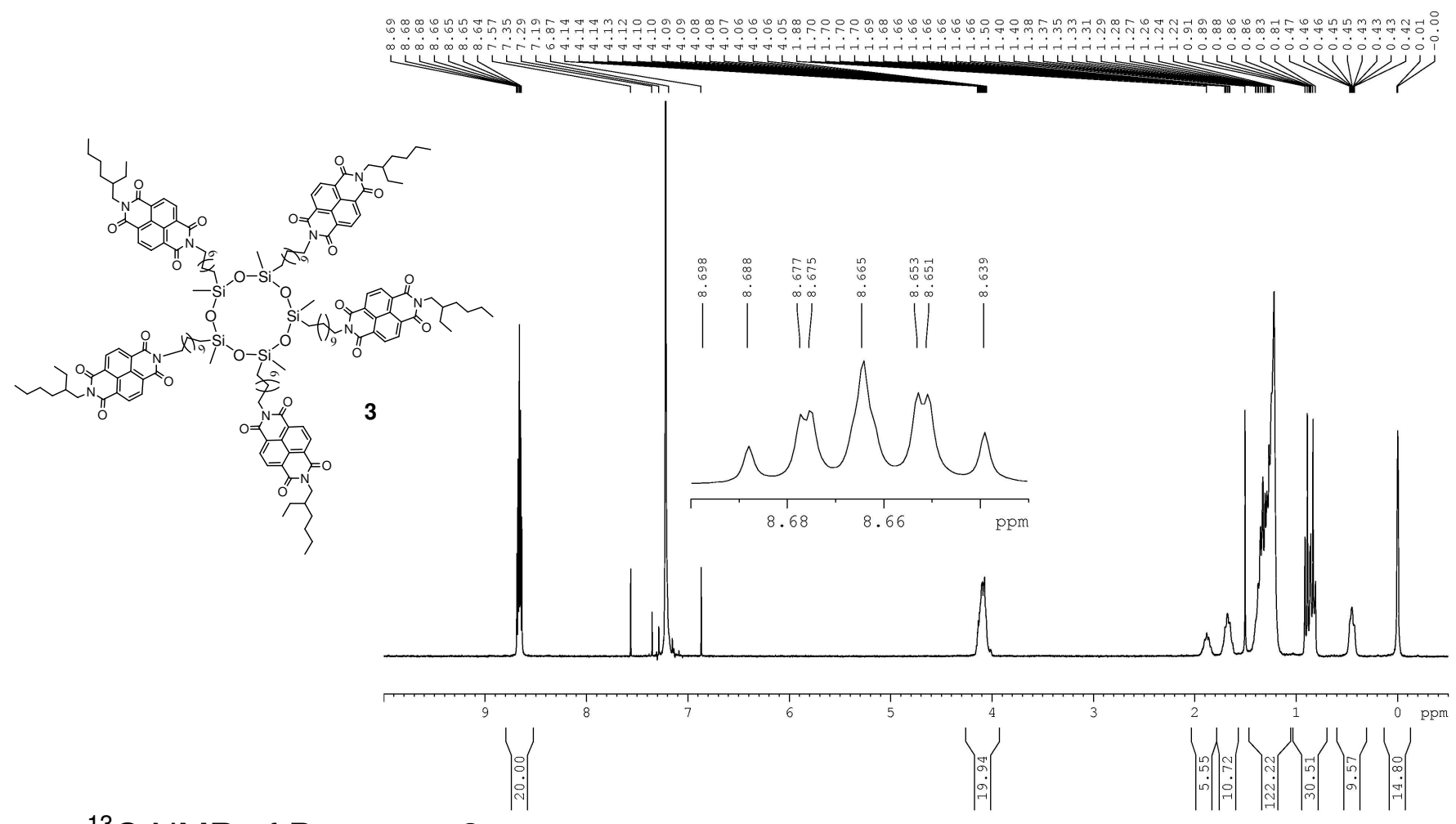

${ }^{13} \mathrm{C}$ NMR of Pentamer 3

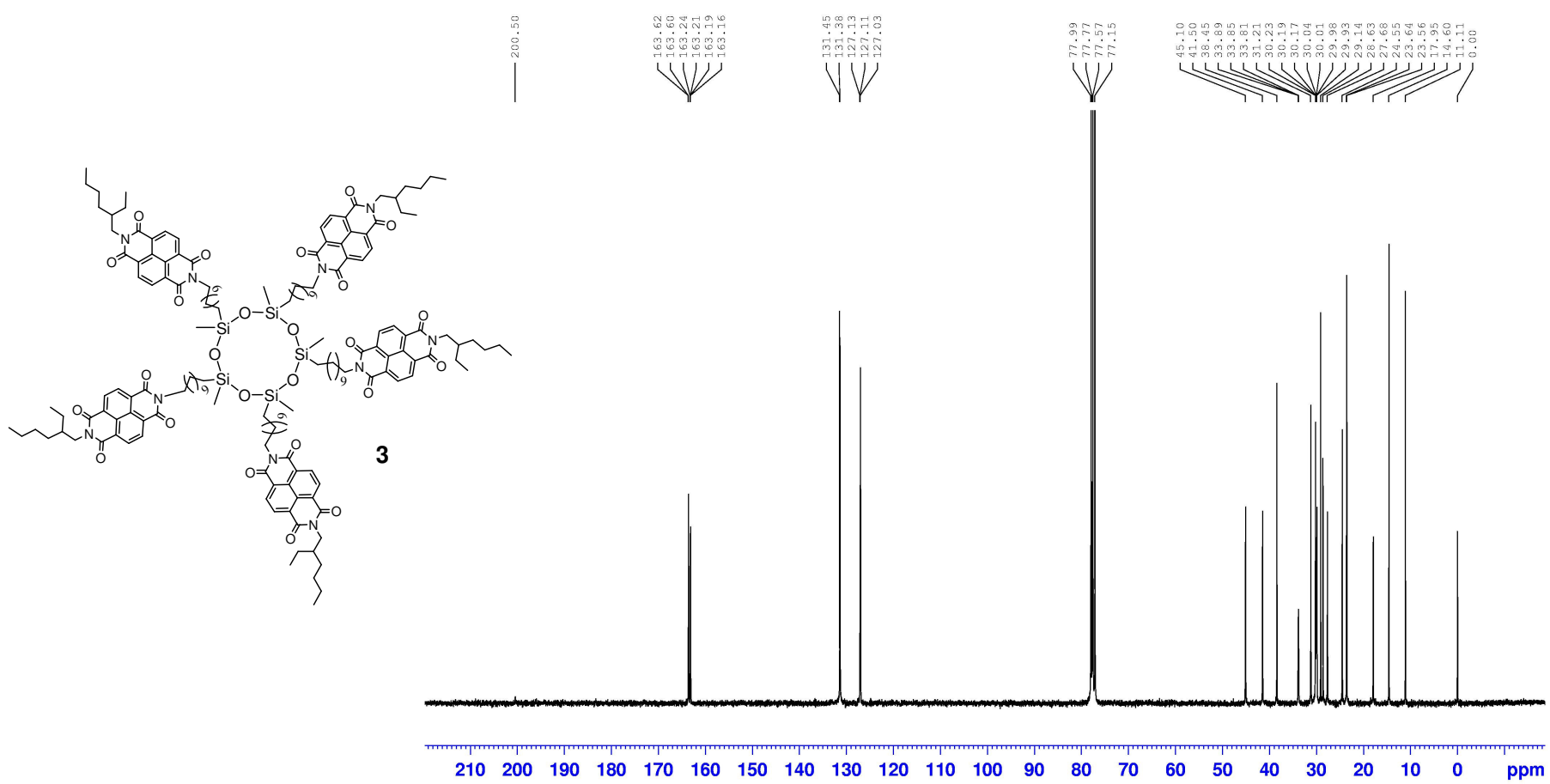


HRMS spectrum of N-(2-ethylhexyl)-N'- (10-undecenyl)naphthalenediimide 4

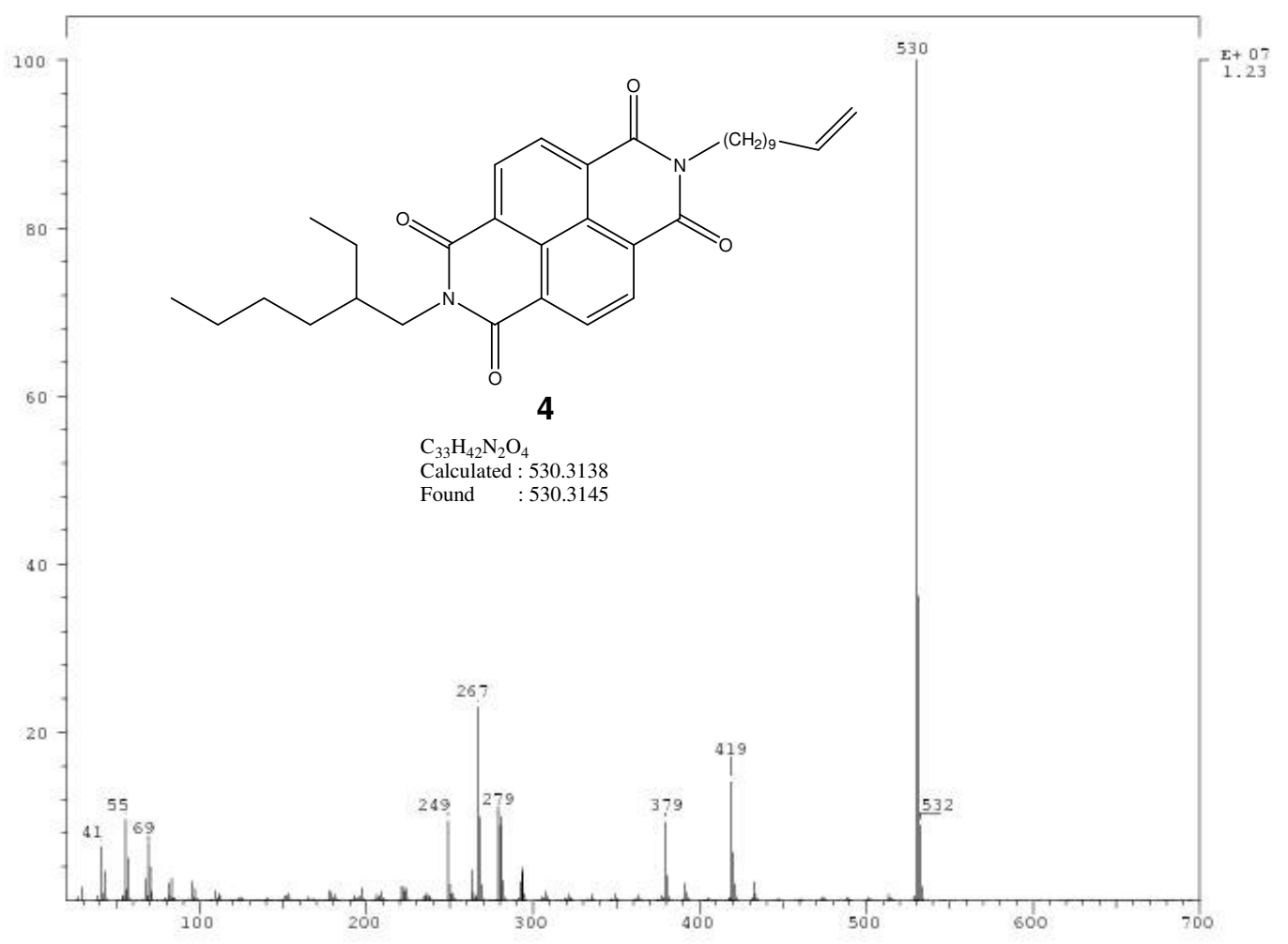

\section{MALDI-TOF spectrum of Dimer 1}

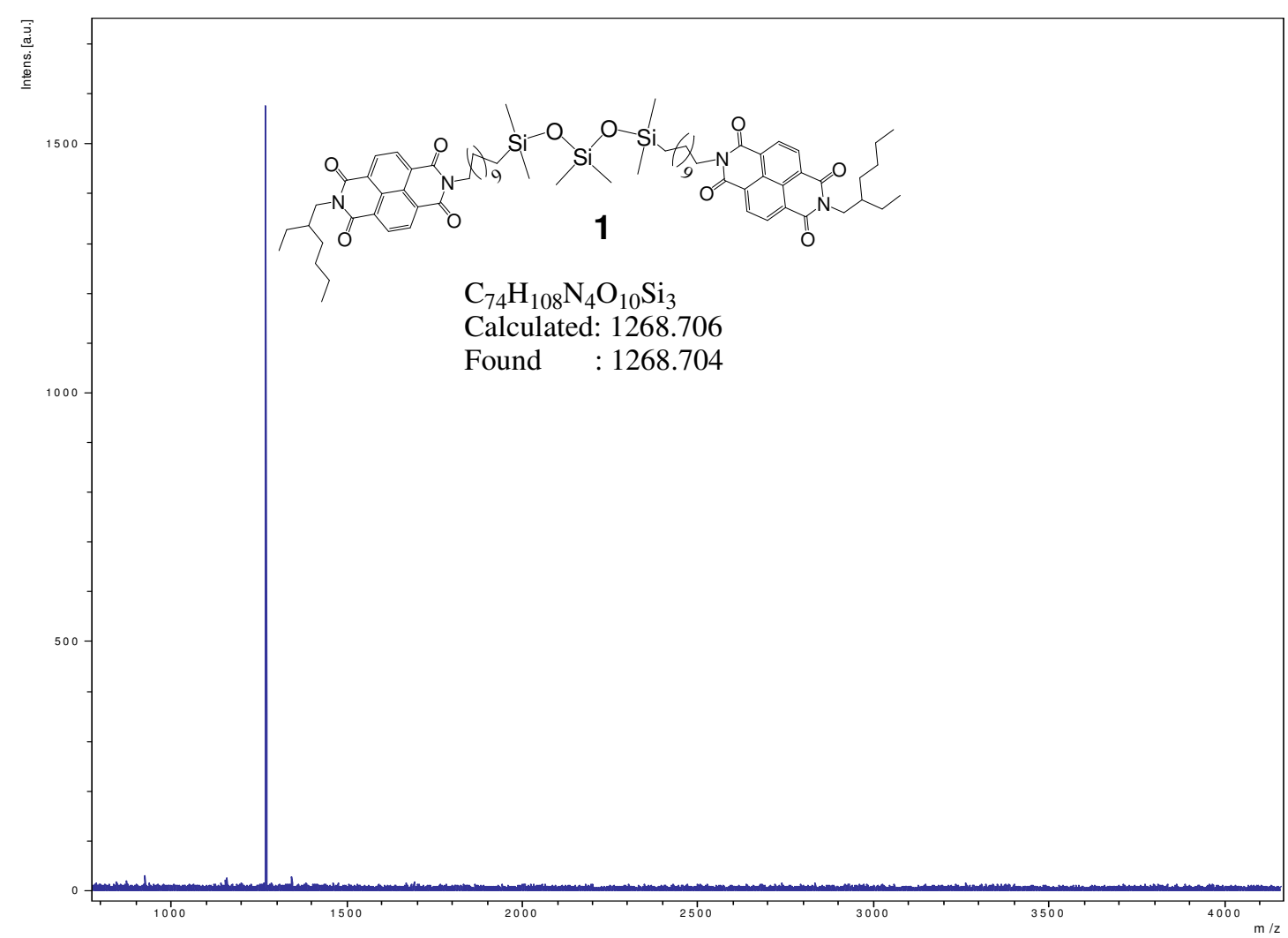




\section{MALDI-TOF spectrum of Tetramer 2}

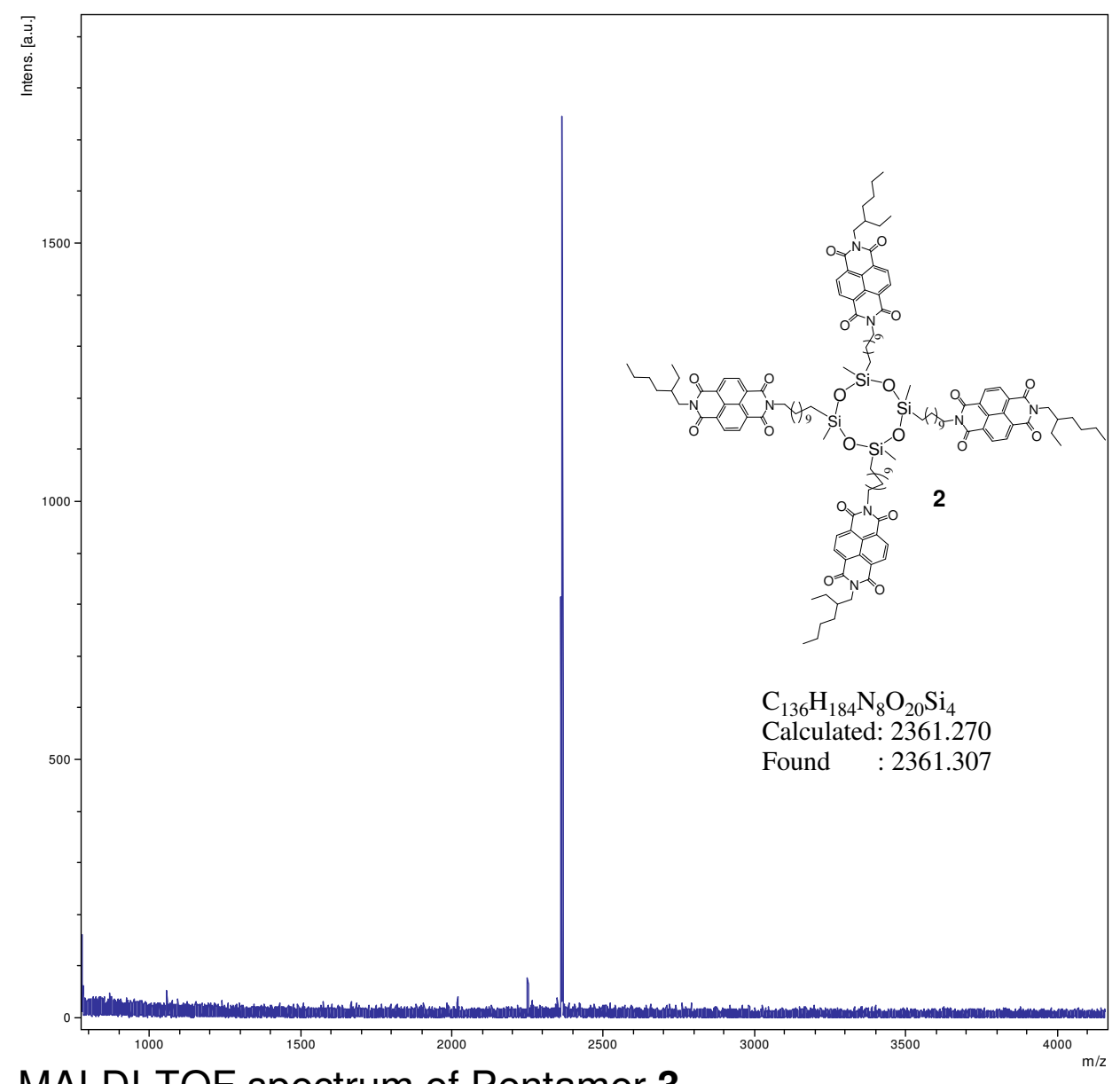

\section{MALDI-TOF spectrum of Pentamer 3}

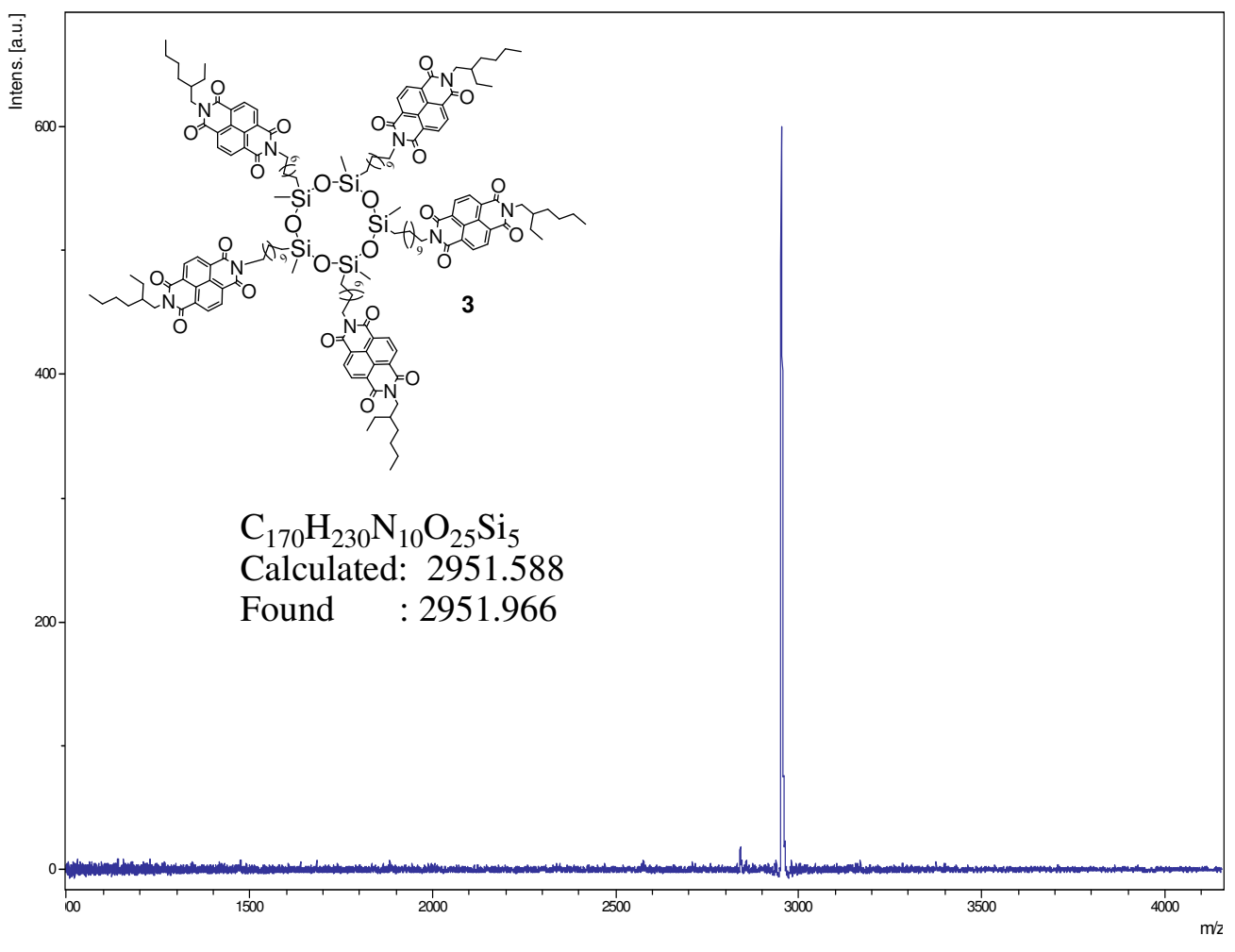




\section{Absorption spectra of 1 and 2 in films (drop-casted from $\mathrm{CHCl}_{3}$ solution)}

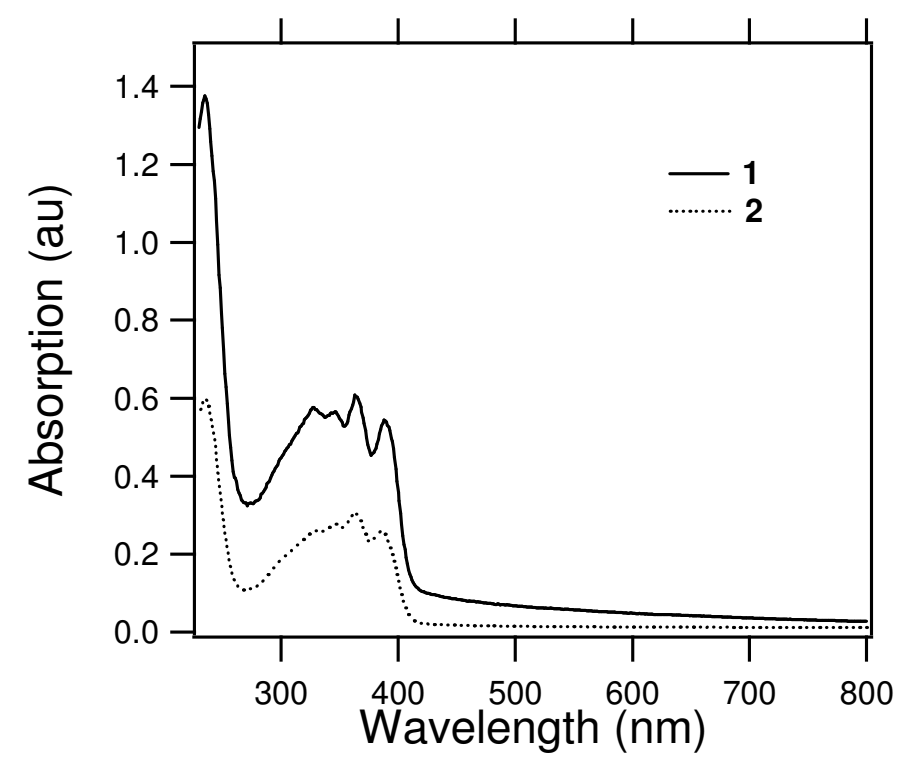

Fluorescence life-time data obtained from $\mathrm{TCSPC}$ (in $\mathrm{CHCl}_{3}$ solution)

\begin{tabular}{|c|c|c|c|c|c|c|c|c|c|}
\hline \multirow{2}{*}{ Compound } & \multirow{2}{*}{ Concentration (M) } & \multicolumn{7}{|c|}{ Lifetimes (ns) } \\
\cline { 3 - 11 } & & $\mathbf{A}_{\mathbf{1}}$ & $\tau_{\mathbf{1}}$ & $\mathbf{A}_{\mathbf{2}}$ & $\tau_{2}$ & $\mathbf{A}_{\mathbf{3}}$ & $\tau_{3}$ & $\mathbf{A}_{\mathbf{4}}$ & $\tau_{4}$ \\
\hline $\mathbf{1}$ & $9.76 \mathrm{E}-07$ & 74 & 0.013 & 8 & 0.277 & 8 & 1.605 & 9 & 8.639 \\
\hline $\mathbf{2}$ & $9.39 \mathrm{E}-07$ & 45 & 0.014 & 10 & 0.318 & 21 & 2.05 & 24 & 7.334 \\
\hline $\mathbf{3}$ & $9.75 \mathrm{E}-07$ & 66 & 0.018 & 15 & 0.217 & 20 & 18.557 & & \\
\hline
\end{tabular}

\section{References:}

Syntheses of compounds 5 \& 6 are described in: Sieval, A. B.; Linke, R.; Heij, G.; Meijer, G.; Zuilhof, H.; Sudhölter, E. J. R. Langmuir 2001, 17, 7554-7559.

Synthesis of compound 7 is described in: Ganesan, P.; Yang, X. N.; Loos, J.; Savenije, T. J.; Abellon, R. D.; Zuilhof, H.; Sudhölter, E. J. R. J. Am. Chem. Soc. 2005, 127, 14530-14531. 